\title{
Chitinozoan biostratigraphy and lithological characteristics of the Lower and Upper Visby boundary beds in the Ireviken 3 section, Northwest Gotland
}

\author{
Viiu Nestor ${ }^{\mathrm{a}}$, Rein Einasto ${ }^{\mathrm{a}}$, and David K. Loydell ${ }^{\mathrm{b}}$ \\ ${ }^{a}$ Institute of Geology, Tallinn Technical University, Estonia pst. 7, 10143 Tallinn, Estonia; \\ vnestor@gi.ee; einasto@gi.ee \\ ${ }^{\mathrm{b}}$ School of Earth and Environmental Sciences, University of Portsmouth, Burnaby Road, \\ Portsmouth PO1 3QL, UK; David.Loydell@port.ac.uk
}

Received 22 January 2002, in revised form 10 June 2002

\begin{abstract}
The lithology of the middle part of the cliff section at Ireviken 3 is described and the succession of chitinozoans through the Lower and Upper Visby formations is documented. Ten chitinozoan event levels are identified, based upon appearances or disappearances of chitinozoan taxa. Of these, all but two are considered to reflect local, rather than basinwide, changes in assemblages. Correlation of two chitinozoan event levels with Estonian and Latvian sequences is possible: level 1 may correlate with the base of the Margachitina margaritana Biozone and level 8 approximately with the base of Interzone IV.
\end{abstract}

Key words: Silurian, Llandovery, Wenlock, Visby formations, chitinozoans, conodonts, Ireviken Event, Gotland, Sweden.

\section{INTRODUCTION}

The Ireviken Event is a protracted interval of pronounced changes in the composition of conodont faunas (Aldridge et al. 1993; Jeppsson 1997, 1998) extending from the late Llandovery (Telychian) into the early Wenlock (Sheinwoodian). It thus encompasses the Llandovery-Wenlock boundary, as defined by the "golden spike" at Hughley Brook, Shropshire, England, which correlates approximately with Datum 2 of the event (Jeppsson \& Männik 1993).

The Ireviken Event was initially identified in Gotland, Sweden, and is named after localities on the NW coast of this island (see Laufeld 1974a, p. 71 for details). The conodont faunas from this area have been studied intensively and David Gelsthorpe (University of Leicester, UK) is currently engaged in a detailed study of acritarch diversity changes through the Ireviken Event in NW Gotland. 
Chitinozoans from the Ireviken 3 section were first studied by Laufeld (1974b, p. 24) who analysed nine samples from the $19 \mathrm{~m}$ thick section: five samples from the Lower Visby Formation, two samples from the Upper Visby Formation and two from the Högklint Formation (the highest sample, from the top of the cliff, is not shown in Fig. 1). The same section was studied in 1994 by V. Nestor and R. Einasto: a detailed lithological description of the boundary interval of the Lower and Upper Visby beds was compiled and nine chitinozoan samples were taken. Laufeld's published data are also used in the present paper. All samples and species ranges are plotted in Fig. 1. The purpose of this paper is to examine the effect of the Ireviken Event upon chitinozoans in the "type area" for the event, Ireviken 3 in NW Gotland. We discuss also correlation of the chitinozoan event levels recognized with the conodont datums in NW Gotland and with sequences elsewhere in the Baltic region.

\section{DESCRIPTION OF THE SECTION}

The Lower Visby marlstones, Upper Visby argillaceous limestones with marlstone intercalations, and the Högklint crinoidal (pelmatozoan) grainstones with reef-bodies are exposed in the Ireviken 3 section (Fig. 1). In the present paper only the approx. $1.50 \mathrm{~m}$ thick boundary interval of the Lower and Upper Visby formations is characterized in detail (Fig. 2). It corresponds to the middle part of the Ireviken Event in the succession of conodonts (from datum 4 to datum 6.2 of Jeppsson \& Männik 1993). Below this interval the cliff face was covered by debris; above, the sheer cliff face was practically inaccessible. The described section contains some tempestite interlayers and basal, transgressive packstone or grainstone interbeds with discontinuity surfaces at their base. The thickness of these interlayers varies from 3 to $7 \mathrm{~cm}$.

The described interval is subdivided into two main parts (complexes), the junction of which does not coincide with the traditional Lower/Upper Visby boundary (0-level in Fig. 2), but is situated at a distinct pyritized discontinuity surface, about $0.7 \mathrm{~m}$ higher. Below, a description of the section in ascending order is presented (beds $-3,-2$, and -1 were excavated from the debris; see Fig. 2).

I. Lower complex $(110 \mathrm{~cm}+)$. Marlstone (marlstone : limestone ratio is about $4: 1)$ prevails and this complex is more argillaceous than the overlying complex. The limestone interlayers, up to $2-3 \mathrm{~cm}$ thick, are represented by poorly sorted (varigrained) packstone or, rarely, grainstone of probably tempestite origin. The most common fossils are representatives of the open-shelf groups: rugose corals, bryozoans, brachiopods. Bed-by-bed description of the section in ascending order is as follows:

Bed -3 $(23 \mathrm{~cm}+)$. Horizontally-bedded marlstone with nodules of argillaceous limestone at certain levels; the upper surface is even and bears weak signs of erosion (denudation). 


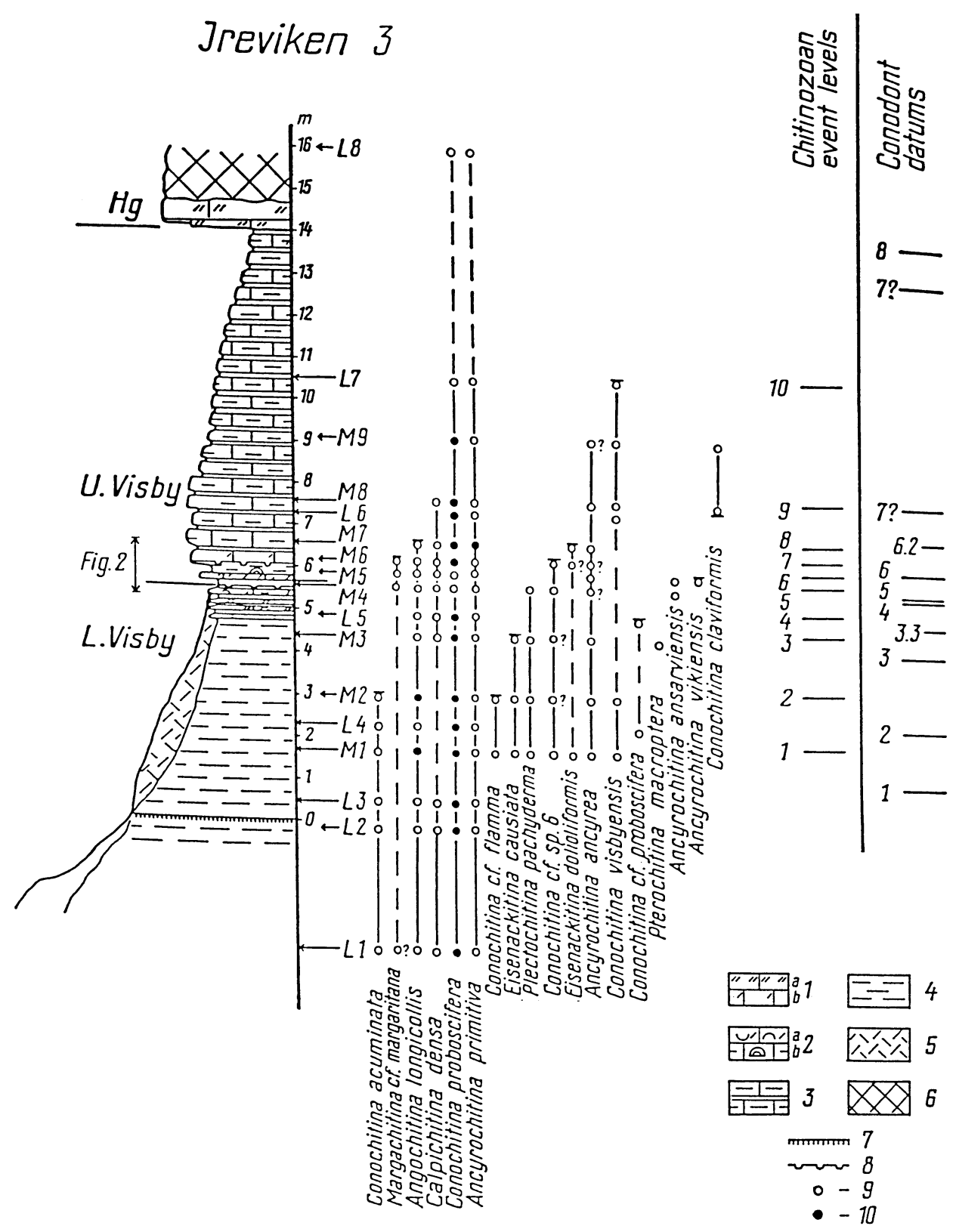

Fig. 1. Ranges of chitinozoan species in the reference section of Ireviken 3. L, samples from Laufeld 1974b; M, our samples (M8 and M9 were taken about $40 \mathrm{~m}$ NE of the main section). Legend: 1 - a, coarse skeletal grainstone, $\mathrm{b}$, fine skeletal grainstone; 2 - a, skeletal-coquinoid floatstone, $\mathrm{b}$, argillaceous limestone with stromatoporoids; 3, argillaceous limestone-marlstone interbedding; 4, marlstone; 5 , debris; 6 , reef limestone; 7 , metabentonite layer; 8 , discontinuity surface; 9 , occurrence of species; 10 , abundant occurrence of species. 


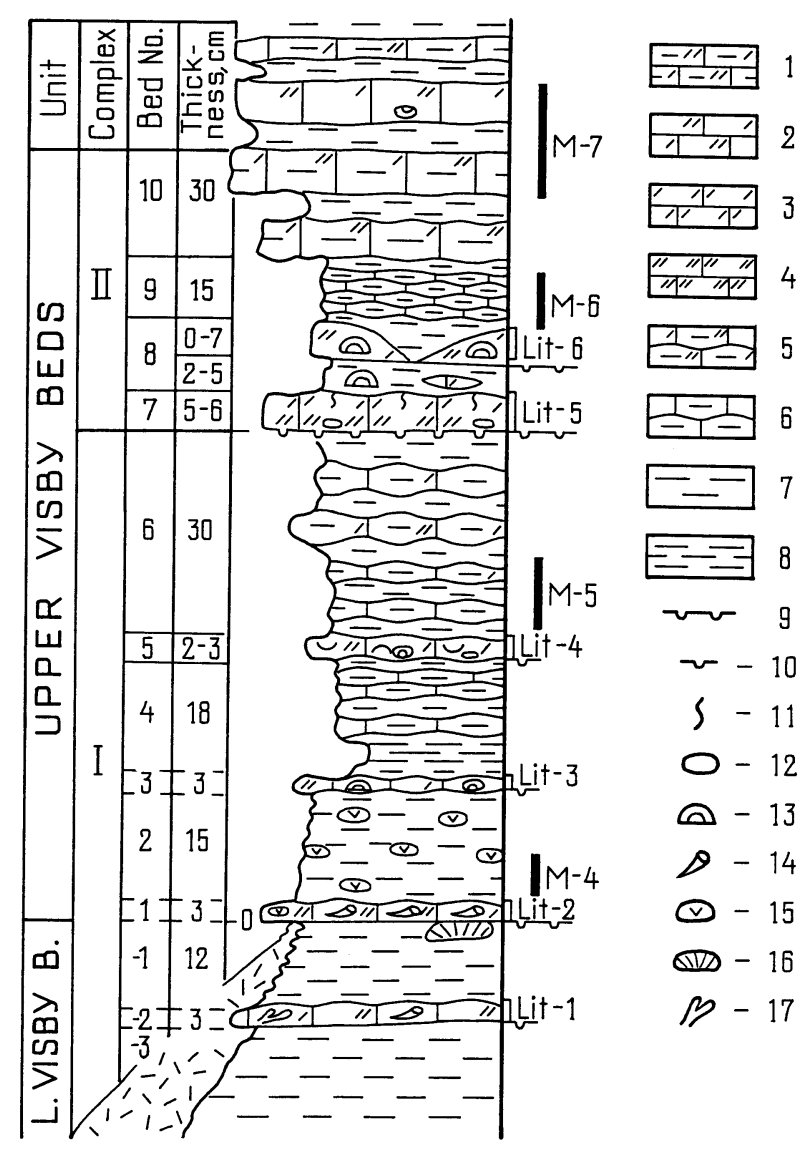

Fig. 2. Lithological log of the boundary interval of the Lower and Upper Visby formations at Ireviken 3 (compiled by R. Einasto). M, chitinozoan samples; Lit, lithological samples. Legend: 1, argillaceous unsorted skeletal packstone; 2, unsorted skeletal packstone; 3, fine skeletal grainstone; 4, coarse skeletal grainstone; 5, nodular argillaceous unsorted skeletal packstone and wackestone; 6, argillaceous nodular limestone; 7, calcareous marlstone; 8 , argillaceous marlstone; 9 , discontinuity surface; 10 , weakly expressed discontinuity surface; 11 , vertical burrows; 12 , limestone pebbles; 13, stromatoporoids; 14 , rugose corals, 15 , Phaulactis sp.; 16, tabulate corals; 17 , bryozoans.

Bed -2 $(3 \mathrm{~cm})$. Tempestite interlayer of bioclastic packstone with rugose corals, ossicles of crinoids and fragments of bryozoans; the upper surface is wavy with symmetrical ripple-marks.

Bed -1 $(12 \mathrm{~cm})$. Marlstone with rare nodules of argillaceous limestone; the upper surface is even with distinct signs of denudation (top of an in situ favositid coral is truncated and smooth) and designates the traditional boundary between the Lower and Upper Visby formations, $5.5 \mathrm{~m}$ above the reference bentonite layer (see Jeppsson \& Männik 1993).

Bed $1(3 \mathrm{~cm})$. Unsorted (varigrained) crinoidal packstone with common rugose corals (Phaulactis, identified by B. Neuman); the upper surface is irregularly wavy. 
Bed $2(15 \mathrm{~cm})$. Wavy-bedded to fine-nodular calcareous marlstone with common rugose corals (Phaulactis) and a wavy, slightly pyritized discontinuity surface at the top.

Bed $3(2-3 \mathrm{~cm})$. Unsorted (varigrained) skeletal packstone storm-layer with common stromatoporoids and a wavy upper surface.

Bed $4(18 \mathrm{~cm})$. Fine-nodular argillaceous marlstone (lower) to argillaceous limestone (upper) with a wavy, limonitic discontinuity surface at the top.

Bed $5(2-3 \mathrm{~cm})$. Unsorted bioclastic to coquinoid packstone tempestite (storm-layer) with fine rounded pebbles at the base.

Bed $6(30 \mathrm{~cm})$. Calcareous marlstone with wavy-bedded to fine-nodular interlayers of argillaceous limestone. A wavy layer of argillaceous wackestone occurs in the middle of the interval. An even, burrowed discontinuity surface with strong limonitic impregnation and signs of erosion occurs at the top of the bed and designates a boundary of the field-scale (Einsele et al. 1991) or mesocyclite, $6.2 \mathrm{~m}$ above the reference bentonite layer.

II. Upper complex $(52 \mathrm{~cm}+)$. Limestone-marlstone intercalation with limestone prevailing ( $3: 2$ to $2: 1$ ), often represented by pelmatozoan grainstone with rounded skeletons of stromatoporoids suggesting a high-energy shoal environment. The succession of the beds is as follows:

Bed 7 (5-6 cm). Grainstone with graded bedding: a coarse-grained floatstone with fine (diameter less than $0.5 \mathrm{~cm}$ ) rounded lithoclasts grades upwards into pure, well-sorted, fine-grained grainstone. The wavy upper surface of the bed is represented by reworked ripple-marks with common burrows.

Bed $8(2-12 \mathrm{~cm})$. Argillaceous marlstone or calcareous mudstone with common, partly rounded skeletons of stromatoporoids representing a tempestite bioconglomerate in an argillaceous matrix. In the upper part of bed 8 occur isolated large ripples with flat bases, consisting of crinoidal grainstone with stromatoporoid pebbles.

Bed $9(15 \mathrm{~cm})$. Wavy-bedded to fine-nodular calcareous marlstone similar to that in bed 6; the upper surface is wavy but without a distinct break.

Bed $10(30 \mathrm{~cm}+)$. Thin-bedded intercalation of packstone-wackestone layers with calcareous marlstone.

The boundary between complexes I and II, i.e. between beds 6 and 7, is marked by a distinct, strongly pyritized discontinuity surface overlain by bed 7 of skeletal grainstone with graded bedding. In complex I, marlstone dominates and grainstone interlayers and stromatoporoids are almost lacking. In complex II, on the other hand, the frequency of the limestone interlayers, including grainstones, increases abruptly and stromatoporoids become quite common.

This boundary, about $0.7 \mathrm{~m}$ above the traditional boundary between the Lower and Upper Visby formations, designates the most distinct lithofacies boundary in the present section, comparable with the sequence boundary of field-scale cyclites. It coincides approximately with Datum 6 of the Ireviken Event in the conodont succession (disappearance of Pterospathodus procerus; Jeppsson \& Männik 1993; Jeppsson 1997). Beds 1-6 in the Upper Visby Formation represent a regressive 
part of the cyclite, followed by a definite break in sedimentation which is marked by a strongly pyritized discontinuity surface between beds 6 and 7 . Beds 7 and 8 together form a typical, transgressive basal part of the next field-scale cyclite or parasequence.

Assuming that the correlations of the graptolite and conodont biozonations that apply to the Ohessare (Loydell et al. 1998) and Aizpute-41 (Loydell et al. in press) cores are valid also for Gotland, the lithological succession described above can be seen to be consistent with the global sea-level curve produced by Loydell (1998). The marl-rich lower part of the section (complex I) would have been deposited during a period of generally high global sea level, during the murchisoni Zone. The prominent discontinuity surface at the base of complex II and the shallower water indicators within this complex would be the result of the regression and/or lower global sea levels that prevailed during the subsequent firmus and riccartonensis zones.

\section{THE SUCCESSION OF CHITINOZOANS AT IREVIKEN 3}

The overall pattern shown by the chitinozoans at Ireviken 3 is one of diversity decline. This contrasts with Laufeld's (1974b, p. 24) results, which show diversity stable at five or six taxa per sample throughout the Lower and Upper Visby formations.

Ten changes in the chitinozoan assemblages are recognized in the Ireviken 3 sequence. These are disappearances and appearances of chitinozoan taxa, recorded here as event levels 1-10. All levels are illustrated in Fig. 1 together with conodont datums (from Jeppsson \& Männik 1993). Selected chitinozoan species from the sequence are illustrated in Pl. I.

The event levels are as follows (from below):

Level 1. At the level of sample M1 several species appear, of which Plectochitina pachyderma and Conochitina cf. flamma are the most important (appear in the East Baltic sections at the base of the Wenlock; Nestor 1994), the other species are known elsewhere from lower in the Telychian (upper Llandovery) and cross the Llandovery-Wenlock boundary. Level 1 is the only chitinozoan level below conodont Datum 2 and thus probably lies within the uppermost Telychian (Llandovery) rather than the Sheinwoodian (Wenlock) (see Jeppsson \& Männik 1993).

Level 2. In sample M2 the last specimens of Conochitina acuminata and C. cf. flamma were found. In the Banwy River section the highest C. acuminata occur in the uppermost insectus Biozone (Mullins \& Loydell 2001).

Level 3. In sample M3 Pterochitina macroptera appears and Eisenackitina causiata disappears. Elsewhere (e.g. Banwy River section, Wales, and Aizpute-41 core, Latvia; Mullins \& Loydell 2001; Loydell et al. in press) E. causiata is present through to at least the lower part of the riccartonensis graptolite Biozone. 

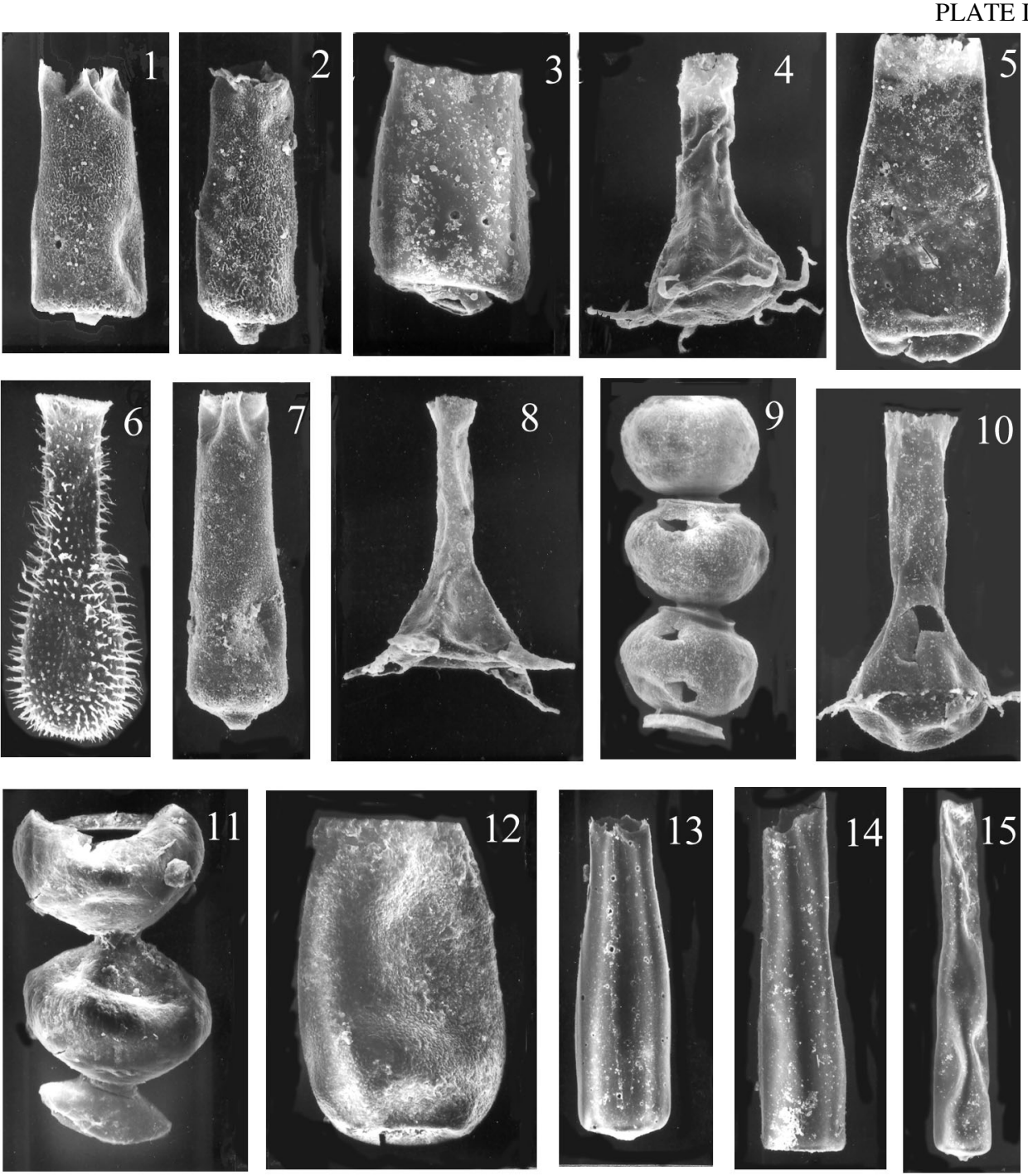

Selected chitinozoan species from the Lower and Upper Visby Beds at Ireviken 3 on Gotland.

1, Conochitina visbyensis Laufeld, 1974, 355-1, Lower Visby Beds, sample M1, ×210. 2, Conochitina acuminata Eisenack, 1959, 355-2, Lower Visby Beds, sample M1, $\times 200$. 3, Eisenackitina causiata Verniers, 1999, 355-3, Lower Visby Beds, sample M1, ×320. 4, Ancyrochitina ancyrea (Eisenack, 1931), 355-4, Lower Visby Beds, sample M1, ×290. 5, Conochitina cf. sp. 6 (of Nestor, 1994), 355-5, Lower Visby Beds, sample M1, ×200. 6, Angochitina longicollis Eisenack, 1959, 355-6, Lower Visby Beds, sample M1, $\times 180.7$, Conochitina cf. flamma Laufeld, 1974, 355-7, Lower Visby Beds, sample M1, $\times 200$. 8, Plectochitina pachyderma Laufeld, 1974, 355-8, Lower Visby Beds, sample M1, $\times 240$. 9, Calpichitina densa (Eisenack, 1962), 355-9, Upper Visby Beds, sample M5, $\times 250$. 10, Ancyrochitina ansarviensis Laufeld, 1974, 355-10, Upper Visby Beds, sample M5, $\times 290$. 11, Margachitina cf. margaritana (Eisenack, 1937), 355-11, Upper Visby Beds, sample M6, $\times 280$. 12, Eisenackitina dolioliformis Umnova, 1976, 355-12, Upper Visby Beds, sample M7, $\times 200$. 13, Conochitina proboscifera Eisenack, 1937, 355-13, Upper Visby Beds, sample M6, $\times 85$. 14, 15, Conochitina claviformis Eisenack, 1931, Upper Visby Beds, sample M9: 14 - 355-14, ×120; $15-355-15, \times 95$. 
Level 4. The next level, at sample point L5, is characterized by the disappearance of Conochitina cf. proboscifera (sensu Laufeld, 1994).

Level 5. The event at the level of sample M4 is marked by the disappearance of Plectochitina pachyderma from the section (it reappears in younger strata, in southwestern facies of the Högklint Formation; Laufeld 1974b, p. 47) and the appearance of Ancyrochitina ansarviensis.

Level 6. In sample M5 the last Ancyrochitina ansarviensis occurred (according to Laufeld 1974b it occurs also in the upper part of the Högklint Beds) and A. vikiensis was found. The latter species occurs in small numbers in the upper Telychian of the Viki core (Nestor 1994, fig. 14).

Level 7. The level of sample M6 is marked by the disappearance of Conochitina cf. sp. 6 (after Nestor 1994) and Margachitina cf. margaritana.

Level 8. The next event at sample M7 is the most remarkable in the succession of chitinozoans. It is expressed by the disappearance of Angochitina longicollis and Eisenackitina dolioliformis occurring abundantly in the Telychian and lower Sheinwoodian worldwide. In the Ohesaare core, Saaremaa, Estonia (Nestor 1994; Loydell et al. 1998) and Aizpute-41 core, Latvia, A. longicollis disappears below, and E. dolioliformis within chitinozoan Interzone IV. In both Ohesaare and Aizpute-41 cores the base of this interzone correlates approximately with the base of the firmus graptolite Biozone. In Wales, however, A. longicollis has its highest occurrence in the lower riccartonensis graptolite Biozone (Verniers 1999; Mullins \& Loydell 2001).

Level 9. This level is marked by the disappearance of Calpichitina densa in sample M8, although rare specimens of that species may occur in younger strata, in Högklint Beds of Gotland (Laufeld 1974b) and Ninase Member of some core sections in Saaremaa (Nestor 1994). Remarkable is the appearance of Conochitina claviformis at the same level. This species occurs first in small numbers in assemblages dominated by C. proboscifera, but increases in abundance in the Slite Group of Gotland (Nestor \& Einasto 1997).

Level 10. The last event, at the level of sample L7, is characterized by the disappearance of Conochitina visbyensis.

Of the 18 chitinozoan taxa present in the Lower and Upper Visby formations of the Ireviken 3 section, ten became extinct during the Ireviken Event. The remainder became extinct either later in the Wenlock or in the Ludlow. It is worth mentioning that in the East Baltic sections all together 15 species became extinct approximately in the same interval of the Ireviken Event (see Nestor 1994).

\section{DISCUSSION}

In terms of chitinozoan biozones, the samples below chitinozoan event level 1 could belong either to the Margachitina banwyensis or to the M. margaritana Biozone, as Laufeld's (1974b, p. 24) record (in sample L1) may be M. banwyensis (Mullins \& Loydell 2001). In the Banwy River section M. banwyensis ranges from the upper lapworthi graptolite Biozone through to the top of the centrifugus 
graptolite Biozone. From level 1 to level 8 the strata probably belong to the M. margaritana Biozone and strata above level 8 belong to Interzone IV of Nestor (1994), defined by the disappearance of A. longicollis.

M. margaritana is a very widespread taxon (Verniers et al. 1995; Mullins 2000), giving its name to a biozone spanning the Llandovery-Wenlock boundary. Perhaps the absence of specimens of this species in samples M1-L5 at Ireviken 3 may have a palaeoenvironmental explanation, with the M. margaritana-producing organism favouring environments away from bioherms such as those that characterize the Ireviken 3 section. Laufeld (1974b, p. 121) noted that chitinozoans as a group became significantly more abundant "in the seaward direction from bioherms". Further detailed quantitative study may reveal chitinozoan biofacies (such as those recognized by Nestor 1998 in the Rhuddanian of the East Baltic region) in the interval represented by the Lower and Upper Visby formations.

Sample M6 is close to the level of conodont datum 6 (Fig. 2). In the Ohesaare core this level lies close to the base of the firmus graptolite Biozone (Loydell et al. 1998); in the Aizpute-41 core it occurs somewhat higher, low in the riccartonensis graptolite Biozone (Loydell et al. in press).

It is interesting that the most significant changes in both chitinozoan and conodont assemblages at Ireviken 3 occur at approximately the same level: chitinozoan event level 1 and conodont datum 2, which are separated by less than $1 \mathrm{~m}$ of strata. In the case of the chitinozoans, level 1 sees the appearance in the section of seven taxa; for the conodonts datum 2 is marked by extinctions (see Jeppsson 1998, fig. 3). It is worth mentioning that the appearance of some chitinozoan taxa at the level of sample M1 may be an artifact, as Laufeld's samples (L1-L3) below sample M1 could be too small $(50 \mathrm{~g})$ to include all species and therefore may contain only the more frequent taxa.

Six chitinozoan taxa disappear in the Ireviken 3 section between chitinozoan event levels 6 and 8 , close to conodont datum 6 , which is marked by the extinction of the genus Pterospathodus. The firmus and early riccartonensis graptolite zones (within which conodont datum 6 lies in Estonia and Latvia; see above) saw a marked decline in graptolite diversity (the murchisoni Event of Štorch 1995; see also Melchin et al. 1998), and thus it seems that this was a time of extinction for chitinozoans, conodonts, and graptolites.

A considerable amount of data is available on the stratigraphical ranges of chitinozoans from Estonia and Latvia (Nestor 1994). Comparison of the ranges of the taxa in the Ireviken 3 section with those in the East Baltic shows great variation in the pattern of occurrence of individual species. Of the ten chitinozoan event levels recognized at Ireviken 3, most appear to represent local changes in assemblages, rather than being a reflection of true global extinctions or originations of particular taxa.

The two chitinozoan event levels, 1 and 8, that may reflect more than just local changes in assemblages have been discussed above. Level 1 (appearance of Plectochitina pachyderma and Conochitina cf. flamma and local appearance of five other taxa) may correlate with the base of the Margachitina margaritana Biozone as recognized in Estonia and Latvia (see Nestor 1994, table 3). As 
mentioned above, chitinozoan level 8 marks the base of Interzone IV (Nestor 1994).

It is difficult to say how many chitinozoan taxa go extinct globally approximately in the interval of the Ireviken Event. According to Verniers et al. (1995) seven species, including Conochitina acuminata, Eisenackitina dolioliformis, Angochitina longicollis, and Calpichitina densa disappear at that level.

In Estonian sections the interval of the Ireviken Event embraces mainly the lower part of the Mustjala Member and Tõlla Beds in the basal part of the Jaani Regional Stage. In addition to the level of the disappearance of A. longicollis, one more important higher level in the chitinozoan succession is recognized in Estonian cores, marked by the extinction of Conochitina proboscifera, the dominant species of the Early Wenlock. This level coincides roughly with the boundary between the Mustjala and Ninase members in the West Estonian islands and with a level within the upper part of the Tõlla Beds in North Latvia, South Estonia, and Sõrve Peninsula of Saaremaa (Nestor 1994). This level has not been recognized in Gotland, but in Estonia it terminates the succession of chitinozoan extinctions during the Early Wenlock. Stratigraphically it lies somewhat higher than the interval of the Ireviken Event.

\section{CONCLUSIONS}

Two distinct lithological complexes, separated by a strongly pyritized discontinuity surface, have been described in the boundary interval of the Lower and Upper Visby formations at the reference section Ireviken 3. This lithofacies boundary, comparable with the sequence boundary of field-scale cyclites, is a distinct lithological marker above the traditional Lower/Upper Visby boundary, defined usually only on the ground of palaeontological findings. This lithological boundary coincides approximately with datum level 6 of the Ireviken Event in the conodont succession and may be a local reflection of the global fall in sea level taking place at this time.

In the Ireviken 3 section, ten of the 18 chitinozoan taxa present became extinct during the Ireviken Event. Ten chitinozoan event levels are distinguished, eight related to the disappearance and two to the appearance of species. The most remarkable is level 8, expressed by the disappearance of A.longicollis and E. dolioliformis, which occur abundantly in the Upper Llandovery and Lower Wenlock worldwide.

\section{ACKNOWLEDGEMENTS}

This study was carried out in cooperation with B. Neuman from Bergen University, who guided two of us (V. Nestor and R. Einasto) during the field work on Gotland. We are also grateful to L. Jeppsson, who kindly advised us on 
the study of the Ireviken section. We thank D. Kaljo and the referees G. Mullins and P. Männik for useful comments and $\mathrm{H}$. Nestor for translating the lithological part of the text, but also V. Mikli for SEM photographs and K. Ronk for drawings. This work was supported by Swedish Royal Academy of Sciences and Estonian Science Foundation (grants Nos. 3749 and 5088) for which the first two authors are most grateful.

\section{REFERENCES}

Aldridge, R. J., Jeppsson, L. \& Dorning, K. J. 1993. Early Silurian oceanic episodes and events. J. Geol. Soc. London, 150, 501-513.

Einsele, G., Ricken, W. \& Seilacher, A. 1991. Cycles and events in stratigraphy - basic concepts and terms. In Cycles and Events in Stratigraphy (Einsele, G., Ricken, W. \& Seilacher, A., eds.), pp. 1-22. Springer-Verlag, Berlin.

Jeppsson, L. 1997. The anatomy of the mid-early Silurian Ireviken Event and a scenario for P-S events. In Paleontological Events. Stratigraphic, Ecological, and Evolutionary Implications (Brett, C. E. \& Baird, G. C., eds.), pp. 451-492. Columbia Univ. Press, New York.

Jeppsson, L. 1998. Silurian oceanic events: summary of general characteristics. In Silurian Cycles: Linkages of Dynamic Stratigraphy with Atmospheric, Oceanic, and Tectonic Changes. James Hall Centennial Volume (Landing, E. \& Johnson, M. E., eds.). New York State Mus. Bull., 491, 239-257.

Jeppsson, L. \& Männik, P. 1993. High-resolution correlations between Gotland and Estonia near the base of the Wenlock. Terra Nova, 5, 348-358.

Laufeld, S. 1974a. Reference localities for palaeontology and geology in the Silurian of Gotland. Sver. Geol. Unders. Ser. C, 705.

Laufeld, S. 1974b. Silurian Chitinozoa from Gotland. Fossils Strata, 5.

Loydell, D. K. 1998. Early Silurian sea-level changes. Geol. Mag., 135, 447-471.

Loydell, D. K., Kaljo, D. \& Männik, P. 1998. Integrated biostratigraphy of the lower Silurian of the Ohesaare core, Saaremaa, Estonia. Geol. Mag., 135, 769-783.

Loydell, D. K., Männik, P. \& Nestor, V. Integrated biostratigraphy of the lower Silurian of the Aizpute-41 core, Latvia. Geol. Mag. (in press).

Melchin, M. J., Koren, T. N. \& Štorch, P. 1998. Global diversity and survivorship patterns of Silurian graptoloids. New York State Mus. Bull., 491, 165-182.

Mullins, G. L. 2000. A chitinozoan morphological lineage and its importance in lower Silurian stratigraphy. Palaeontology, 43, 359-373.

Mullins, G. L. \& Loydell, D. K. 2001. Integrated Silurian chitinozoan and graptolite biostratigraphy of the Banwy River section, Wales. Palaeontology, 44, 731-781.

Nestor, V. 1994. Early Silurian chitinozoans of Estonia and North Latvia. Academia, 4.

Nestor, V. 1998. Chitinozoan biofacies of late early Llandovery (Coronograptus cyphus) age in the East Baltic. Proc. Estonian Acad. Sci. Geol., 47, 219-228.

Nestor, V. \& Einasto, R. 1997. Correlation of some Wenlock outcrop sections of Gotland with the Ohesaare section of Saaremaa, Estonia. Proc. Estonian Acad. Sci. Geol., 46, 155-168.

Storch, P. 1995. Biotic crises and post-crisis recoveries recorded by Silurian planktonic graptolite faunas of the Barrandian area (Czech Republic). Geolines, 3, 59-70.

Verniers, J. 1999. Calibration of Chitinozoa versus graptolite biozonation in the Wenlock of the Builth Wells district (Wales, U.K.), compared with other areas in Avalonia and Baltica. Boll. Soc. Paleont. Italiana, 38, 359-380.

Verniers, J., Nestor, V., Paris, F., Dufka, P., Sutherland, S. \& Van Grootel, G. 1995. A global Chitinozoa biozonation for the Silurian. Geol. Mag., 132, 651-666. 


\title{
Kitinosoade biostratigraafia ning Alam- ja Ülem-Visby piirikihtide iseloomustus Ireviken 3 paljandis (Loode-Gotland)
}

\begin{abstract}
Viiu Nestor, Rein Einasto ja David K. Loydell
Irevikeni sündmuse stratotüüpse paljandi litoloogia on detailselt kirjeldatud. On eristatud kaks litoloogilist kompleksi, mis on eraldatud tugevalt püriidistunud katkestuspinnaga. See piir võib olla seotud globaalse meretaseme langusega ning on selge litoloogiline marker, mis asub pisut kõrgemal (0,7 m) Alam- ja ÜlemVisby kihte lahutavast biostratigraafilisest piirist.

Samast paljandist on määratud kitinosoad ja kindlaks tehtud kümme kitinosoade koosluse muutumistaset, millest on olulisemad esimene tase, mis määrab Margachitina margaritana tsooni alumise piiri, ja kaheksas tase, mis määrab sama tsooni ülemise piiri. Kaheksateistkümnest kitinosoa liigist sureb uuritud intervallis välja kümme. Kogu Siluri ulatuses on see nimetatud grupi jaoks üks peamisi liikide väljasuremistasemeid.
\end{abstract}

\section{Биостратиграфия хитинозой и литологическая характеристика пограничных слоев Нижней и Верхней Висьбю на клифе Иревикен 3 (сз о. Готланд)}

\author{
Вийу Нестор, Рейн Эйнасто и Давид К. Лойделл
}

\footnotetext{
Выделено два литокомплекса с различной частотой и особенностям темпеститовых прослоев. Граница между ними маркирована четкой пиритизированной поверхностью перерыва, служившей естественной границей мезоциклитов. Эта литологически четкая граница расположена несколько выше $(0,7$ м) традиционной биостратиграфической границы между нижними и верхними слоями Висьбю вероятно связана с глобальным понижением уровня мирового океана.

В пограничных слоях лландовери и венлока на клифе Иревикен 3 установлена 10 уровней изменения видового состава хитинозой, из которых более существенными являются первый уровень на нижней границе биозоны Margachitina margaritana и восьмой уровень на ее верхней границе. Из 18 видов в пределах пограничных слоев вымирает 10, что один из более маркантных событий в последовательности хитинозой в силуре.
} 